\title{
Pharmacokinetics of a syrup formulation of amoxycillin-potassium clavulanate in children
}

\author{
Urs B. Schaad, Patrick A. Casey and Anne T. Ravenscroft
}

Division of Paediatric Infectious Diseases, Department of Paediatrics, University of Berne,
Inselspital, CH-3010 Berne, Switzerland, and Beecham Pharmaceuticals,
Chemotherapeutlc Research Centre, Brockham Park, Betchworth, Surrey RH3 7AJ, England

\begin{abstract}
The pharmacokinetics of a syrup formulation consisting of four parts of amoxycillin and one part of potassium clavulanate (Augmentin) were studied in 11 paediatric patients, 3 to 14 years of age. Single oral doses of $25 \mathrm{mg}$ of Augmentin per $\mathrm{kg}$ body weight $(20 \mathrm{mg}$ of amoxycillin per $\mathrm{kg}$ plus $5 \mathrm{mg}$ of potassium clavulanate per $\mathrm{kg}$, i.e. $1 \mathrm{mg}$ of the syrup per $\mathrm{kg}$ ) were administered on an empty stomach, and were well accepted and tolerated. Mean peak plasma concentrations $60-90 \mathrm{~min}$ after dosing were $7.2 \mathrm{mg} / \mathrm{l}$ for amoxycillin and $2.0 \mathrm{mg} / \mathrm{l}$ for clavulanic acid. Mean terminal phase plasma half-lifes were 1.4 and $1.0 \mathrm{~h}$, respectively. It is concluded that $25-\mathrm{mg} / \mathrm{kg}$ doses of this syrup formulation of Augmentin administered three times daily should be adequate therapy for various childhood bacterial infections.
\end{abstract}

\section{Introduction}

Clavulanic acid protects amoxycillin against hydrolysis by $\beta$-lactamases produced by many important pathogens causing paediatric infectious diseases (Hunter et al., 1980; Reading, Farmer \& Cole, 1983). The considerable amount of data reported on pharmacokinetics and clinical experience with amoxycillin-clavulanic acid suggests that the two compounds are pharmacokinetically compatible and that this antimicrobial combination is effective and safe therapy for urinary-tract, respiratory-tract, middle-ear, skin, soft-tissue and intra-abdominal infections caused by susceptible bacteria (Stein \& Gurwith, 1984; Odio et al., 1985).

The purpose of the present study was to evaluate the pharmacokinetics of a syrup formulation consisting of four parts of amoxycillin and one part of clavulanic acid in paediatric patients. Both the presentation in powder sachets and the fruit-flavoured taste of the syrup suspension were specially developed for paediatric use.

\section{Materials and methods}

\section{Study patients}

Pharmacokinetic studies following the oral administration of a single dose of amoxycillin-potassium clavulanate were performed in 11 paediatric patients treated at the Department of Paediatrics, University of Berne, for various non-bacterial diseases. 341 
None of the 11 patients, 7 females and 4 males, had received antimicrobial therapy for at least $72 \mathrm{~h}$ before the study. Ages ranged between 3.1 and 13.8 years (mean \pm S.D., $10.8 \pm 3.2$ years). They had no medical history of previous allergy to $\beta$-lactam compounds, nor of renal or hepatic diseases. Clinically, their hydration and circulation status was judged to be normal. The study protocol was approved by the Institutional Committee on Human Investigations, Department of Paediatrics, University of Berne, and informed parental consent was obtained for all study patients.

\section{Drug administration}

Syrup sachets contained $250 \mathrm{mg}$ of amoxycillin and $62.5 \mathrm{mg}$ of potassium clavulanate (Augmentin Sachet, $312.5 \mathrm{mg}$, batch no C.T. 11942; Beecham Pharmaceuticals, Worthing, England). The complete contents were emptied immediately before use into $10.0 \mathrm{ml}$ of water, resulting in $12.4 \mathrm{ml}$ of syrup suspension containing $20 \mathrm{mg}$ of amoxycillin and $5 \mathrm{mg}$ of potassium clavulanate per $\mathrm{ml}$. On an empty stomach $1 \mathrm{ml}$ of the syrup per $\mathrm{kg}$ body weight ( $20 \mathrm{mg}$ amoxycillin per $\mathrm{kg}$ plus $5 \mathrm{mg}$ clavulanic acid per $\mathrm{kg}$ ) was administered followed by drinking a cupful of water. Adverse reactions (local or systemic) to Augmentin were assessed by clinical observation.

\section{Collection of biological samples}

Blood samples for drug assays were collected from an intravenous heparin lock immediately before the oral dose (predose sample) and at 20,40,60,90,120,180 and $360 \mathrm{~min}$ after drug administration. The blood was immediately mixed with sodium citrate and kept in the refrigerator $\left(4^{\circ} \mathrm{C}\right)$ until centrifuged within 30 min. Plasma samples were stored at $-70^{\circ} \mathrm{C}$ until assayed within one week of collection.

The total urine was collected from 9 of the 11 patients at the following time intervals: -1 to 0,0 to 2,2 to 4 , and 4 to $6 \mathrm{~h}$ after dosing. Urine was sampled from a sterile collection bag (three patients) or by voluntary voiding (six patients). Volumes were recorded, and a $1-\mathrm{ml}$ aliquot from each collection period was mixed with $9 \mathrm{ml}$ of $0.1 \mathrm{M}$ citrate buffer $\mathrm{pH} 6.5$ and stored at $-70^{\circ} \mathrm{C}$ until assayed within one week of collection.

\section{Antibiotic assays}

Amoxycillin was assayed with a standard large plate well diffusion technique using Sarcina lutea (NCTC 8340) as the assay organism. Clavulanic acid concentrations were measured by microbiological assay Klebsiella aerogenes (NCTC 11228) as the assay organism (Schaad, Casey \& Cooper, 1983).

\section{Pharmacokinetic analysis}

Model-independent pharmacokinetic data were determined for amoxycillin and clavulanic acid.

\section{Results}

\section{Plasma concentrations}

Mean plasma concentrations ( \pm S.D.) of amoxycillin and clavulanic acid are shown in Table I. Predose samples were free of either agent. Peak plasma concentrations of each drug were found in most patients 60 or 90 min after the dose, with a range of from 40 to $120 \mathrm{~min}$. Mean peak concentration was $7.23 \mathrm{mg} / \mathrm{l}$ for amoxycillin at $60 \mathrm{~min}$, and 
Table I. Plasma concentrations and ratios of amoxycillin and clavulanic acid in 11 paediatric patients

\begin{tabular}{|c|c|c|c|c|c|c|c|c|}
\hline \multirow[t]{2}{*}{ Drug } & \multirow{2}{*}{$\begin{array}{l}\text { Dosage } \\
(\mathrm{mg} / \mathrm{kg})\end{array}$} & \multicolumn{7}{|c|}{$\begin{array}{c}\text { Mean ( } \pm \mathrm{SD} .) \text { plasma concn }(\mathrm{mg} / \mathrm{l}) \text { and ratios at indicated times } \\
\text { after dose }\end{array}$} \\
\hline & & $20 \mathrm{~min}$ & $40 \mathrm{~min}$ & $1 \mathrm{~h}$ & $1.5 \mathrm{~h}$ & $2 \mathrm{~h}$ & $3 \mathrm{~h}$ & $6 \mathrm{~h}$ \\
\hline amoxycillin & 20 & $\begin{array}{c}2 \cdot 13 \\
(1 \cdot 75)\end{array}$ & $\begin{array}{c}5 \cdot 58 \\
(3 \cdot 83)\end{array}$ & $\begin{array}{c}7 \cdot 23 \\
(4 \cdot 61)\end{array}$ & $\begin{array}{c}7 \cdot 13 \\
(3 \cdot 83)\end{array}$ & $\begin{array}{c}6 \cdot 23 \\
(2 \cdot 61)\end{array}$ & $\begin{array}{c}4 \cdot 54 \\
(1 \cdot 59)\end{array}$ & $\begin{array}{r}1 \cdot 74 \\
(1 \cdot 36)\end{array}$ \\
\hline $\begin{array}{l}\text { clavulanic } \\
\text { acid } \\
\text { ratio of amoxycillin }\end{array}$ & 5 & $\begin{array}{c}0.85 \\
(0.89)\end{array}$ & $\begin{array}{c}1 \cdot 72 \\
(1 \cdot 21)\end{array}$ & $\begin{array}{c}2 \cdot 00 \\
(1 \cdot 02)\end{array}$ & $\begin{array}{c}2.04 \\
(0.71)\end{array}$ & $\begin{array}{l}1.60 \\
(0.65)\end{array}$ & $\begin{array}{c}0 \cdot 79 \\
(0 \cdot 50)\end{array}$ & $\begin{array}{r}0 \cdot 12 \\
(0 \cdot 10)\end{array}$ \\
\hline to clavulanic acid & & $2 \cdot 5$ & $3 \cdot 2$ & $3 \cdot 6$ & $3 \cdot 5$ & 3.9 & $5 \cdot 7$ & $14 \cdot 5$ \\
\hline
\end{tabular}

Tabłe II. Per cent recovery of amoxycillin and clavulanic acid in the urine of 9 paediatric patients

\begin{tabular}{|c|c|c|c|c|c|}
\hline \multirow[t]{2}{*}{ Drug } & \multirow{2}{*}{$\begin{array}{l}\text { Dosage } \\
(\mathrm{mg} / \mathrm{kg})\end{array}$} & \multicolumn{4}{|c|}{$\begin{array}{c}\% \text { recovery ( } \pm \text { S.D. }) \text { in urine at } \\
\text { indicated time intervals after dose }\end{array}$} \\
\hline & & $0-2 \mathrm{~h}$ & $2-4 h$ & $4-6 h$ & $0-6 \mathrm{~h}$ \\
\hline amoxycillin & 20 & $\begin{array}{c}19.9 \\
(10.0)\end{array}$ & $\begin{array}{l}15 \cdot 8 \\
(4 \cdot 5)\end{array}$ & $\begin{array}{c}8 \cdot 0 \\
(4 \cdot 5)\end{array}$ & $\begin{array}{c}43 \cdot 7 \\
(15 \cdot 7)\end{array}$ \\
\hline $\begin{array}{l}\text { clavulanic } \\
\text { acid }\end{array}$ & 5 & $\begin{array}{c}9 \cdot 5 \\
(4 \cdot 0)\end{array}$ & $\begin{array}{r}5 \cdot 4 \\
(2 \cdot 5)\end{array}$ & $\begin{array}{l}3 \cdot 5 \\
(2 \cdot 9)\end{array}$ & $\begin{array}{l}18 \cdot 4 \\
(8 \cdot 7)\end{array}$ \\
\hline
\end{tabular}

$2.04 \mathrm{mg} / \mathrm{l}$ for clavulanic acid at $90 \mathrm{~min}$. At $6 \mathrm{~h}$, the mean plasma levels had fallen to 1.74 and $0.12 \mathrm{mg} / \mathrm{l}$, respectively.

\section{Urine concentrations}

Urine samples collected prior to Augmentin administration contained no detectable amoxycillin or clavulanic acid. The mean values ( \pm S.D.) of cumulative percentage of dose recovered in the urine during the three 2-h intervals from time 0 to $6 \mathrm{~h}$ after dosing are shown in Table II. Urine samples were available from 9 of the 11 study patients. By $6 \mathrm{~h}, 43 \cdot 7 \pm 15 \cdot 7 \%$ of the dose of amoxycillin and $18.4 \pm 8.7 \%$ of that of clavulanic acid were recovered in the urine.

\section{Pharmacokinetic data}

The mean values ( \pm S.D.) of the importanf calculated pharmacokinetic parameters are listed in Table III. The mean terminal plasma half-life was $1.4 \mathrm{~h}$ for amoxycillin and $1.0 \mathrm{~h}$ for clavulanic acid. The mean total plasma clearance rates expressed in relation to body surface area were virtually identical, whereas the renal clearance rate for amoxycillin was more than two times larger than the rate for clavulanic acid (321 versus $135 \mathrm{ml} / \mathrm{min}$ per $1.73 \mathrm{~m}^{2}$ ). 
Tabłe III. Mean pharmacokinetic values ( \pm S.D.)

\begin{tabular}{lccccc}
\hline Drug & $\begin{array}{c}\text { Dosage } \\
(\mathrm{mg} / \mathrm{kg})\end{array}$ & $\begin{array}{c}\text { Plasma } \\
\text { half- } \\
\text { life } \\
(\mathrm{h})\end{array}$ & $\begin{array}{c}\text { Area under } \\
\text { the } \\
\text { curve } \\
(\mathrm{mg} \cdot \mathrm{h} / \mathrm{l})\end{array}$ & $\begin{array}{c}\text { Total plasma } \\
\text { clearance } \\
(\mathrm{ml} / \mathrm{min} \text { per } \\
\left.1.73 \mathrm{~m}^{2}\right)\end{array}$ & $\begin{array}{c}\text { Renal } \\
\text { clearance } \\
(\mathrm{ml} / \mathrm{min} \text { per } \\
\left.1.73 \mathrm{~m}^{2}\right)\end{array}$ \\
\hline amoxycillin & 20 & 1.37 & 24.1 & 788 & 321 \\
clavulanic & 5 & $(0.5)$ & $(8.8)$ & $(337)$ & $(64)$ \\
acid & 1.02 & 5.6 & 789 & 135 \\
& & $(0.4)$ & $(1.5)$ & $(249)$ & $(48)$ \\
\hline
\end{tabular}

Safety

Single doses of Augmentin syrup were well tolerated. Three patients complained of mild nausea without vomiting at approximately $1 \mathrm{~h}$ after ingestion on an empty stomach. No other adverse effects were reported.

\section{Discussion}

The observed plasma concentrations after the study dose of $20 \mathrm{mg}$ of amoxycillin per $\mathrm{kg}$ plus $5 \mathrm{mg}$ of potassium clavulanate per $\mathrm{kg}(25 \mathrm{mg}$ of Augmentin per $\mathrm{kg}$ ) are comparable when adjusted for dose to those reported with a different liquid suspension formulation of Augmentin in children (Nelson, Kusmiesz \& Shelton, 1982). Individual drug serum concentrations show substantial variation as reflected in large S.D. values and broad ranges of peak plasma concentrations of from 2.2 to $15.4 \mathrm{mg} / \mathrm{l}$ for amoxycillin and from 0.6 to $3.5 \mathrm{mg} / \mathrm{l}$ for clavulanic acid. Such individual variation of serum concentrations with Augmentin in paediatric patients has been reported before (Nelson et al., 1982; Béqué et al., 1983; Stein \& Gurwith, 1984) and should be considered as a potential explanation in case of clinical failure of oral Augmentin therapy.

The mean of the observed peak concentrations of clavulanic acid $(2.04 \mathrm{mg} / \mathrm{l})$ is sufficient to render amoxycillin resistant strains of such paediatric pathogens as Haemophilus influenzae, Staphylococcus aureus, H. Klebsiella aerogenes, together with organisms such as Branhamella catarrhalis and Bacteroides fragilis sensitive to amoxycillin (Hunter et al., 1980).

The varying ratios of amoxycillin to clavulanic acid in plasma reflect slightly different absorption, elimination and/or distribution characteristics of the two drug constituents. The decreased ratios observed from 20 to $90 \mathrm{~min}$ after dosing suggest somewhat faster absorption of the clavulanate. This might result in prompt $\beta$-lactamase inhibition by clavulanic acid at the site of infection allowing optimal prevention of amoxycillin destruction by these bacterial enzymes.

The terminal plasma half-lives of clavulanic acid are always slightly shorter than those of amoxycillin and amount to values close to $1 \mathrm{~h}$; the average value in this study was $1.02 \mathrm{~h}$. The renal clearance of amoxycillin was greater than that of clavulanic acid. The values obtained were comparable to those reported in paediatric patients following intravenous dosing (Schaad et al., 1983). The greater renal clearance of amoxycillin than of clavulanic acid is a consequence of the greater renal tubular secretion of 
amoxycillin, in spite of their comparable degrees of protein binding. Urine recovery of amoxycillin and clavulanic acid in this study was lower than in studies in adult volunteers following oral administration (Adam, de Visser \& Koeppe, 1982). In the absence of any data on the fraction of the dose absorbed it is not possible to distinguish between the possible explanations of inter subject variation, reduced absorption or greater non renal elimination compared with other patients.

Mild nausea approximately one hour after drug ingestion in three study patients most probably was related to the administration on an empty stomach. The single doses of Augmentin were otherwise well tolerated and loose stools or diarrhoea were not observed. Palatability of the syrup formulation was judged as pleasant by all of the children.

On the basis of these pharmacokinetic data in children, coupled with data on the in vitro antimicrobial activity (Hunter et al., 1980; Reading et al., 1983) and the clinical experience (Fleisher, Wilmott \& Campos, 1983; Stein \& Gurwith, 1984; Odio et al., 1985), a dosage schedule of $25 \mathrm{mg}$ of the studied syrup formulation of Augmentin per kg body weight ( $20 \mathrm{mg}$ of amoxycillin per $\mathrm{kg}$ plus $5 \mathrm{mg}$ of potassium clavulanate per $\mathrm{kg}$ ) administered three times daily is recommended to treat various childhood bacterial infections. These pharmacokinetic results in patients aged between 3 and 14 years suggest that Augmentin syrup is a potentially useful drug formulation for treatment of acute otitis media, sinusitis, cellulitis, urinary-tract infection, and bronchopneumonia of suspected bacterial aetiology in paediatric patients in this age range.

\section{References}

Adam, D., de Visser, I. \& Koeppe, P. (1982). Pharmacokinetics of amoxicillin and clavulanic acid administered alone and in combination. Antimicrobial Agents and Chemotherapy 22, 353-7.

Bégué, F., Quiniou, F., Nocquet, N., Gaillard, C. \& Safran, C. (1983). Pharmacokinetics of Augmentin in children. Proceedings of the European Symposium on Augmentin. Scheveningen, June 28-29, 1982, pp. 319-23.

Fleischer, G. R., Wilmoth, C. M. \& Campos, J. M. (1983). Amoxicillin combined with clavulanic acid for the treatment of soft tissue infections in children. Antimicrobial Agents and Chemotherapy 24, 679-81.

Hunter, P. A., Coleman, K., Fisher, J. \& Taylor, D. (1980). In vitro synergistic properties of clavulanic acid, with ampicillin, amoxycillin and ticarcillin. Journal of Antimicrobial Chemotherapy 6, 455-70.

Münch, R., Lüthy, R., Blaser, J. \& Siegenthaler W. (1981). Human pharmacokinetics and CSF penetration of clavulanic acid. Journal of Antimicrobial Chemotherapy 8, 29-37.

Nelson, J. D., Kusmiesz, H. \& Shelton, S. (1982). Pharmacokinetics of potassium clavulanate in combination with amoxicillin in pediatric patients. Antimicrobial Agents and Chemotherapy 21, 681-2.

Odio, C. M., Kusmiesz, H., Shelton, S. \& Nelson, J. D. (1985). Comparative treatment trial of Augmentin versus cefaclor for acute otitis media with effusion. Pediatrics 75, 819-26.

Reading, C., Farmer, T. \& Cole, M. (1983). The beta-lactamase stability of amoxycillin with the beta-lactamase inhibitor, clavulanic acid. Journal of Antimicrobial Chemotherapy 11, 27-32.

Schaad, U. B., Casey, P. A. \& Cooper D. L. (1983). Single-dose pharmacokinetics of intravenous clavulanic acid with amoxycillin in pediatric patients. Antimicrobial Agents and Chemotherapy 23, 252-5.

Stein, G. E. \& Gurwith M. J. (1984). Amoxicillin-potassium clavulanate, a beta-lactamaseresistant antibiotic combination. Clinical Pharmacy 3, 591-9.

(Manuscript accepted 18 September 1985) 